Social Sciences on Contemporary Turkey

18 | 2014

(Hi)stories of Honor in Ottoman Societies

\title{
The Precarious Intimacy of Honor in Late Ottoman Accounts of Para-militarism and Banditry
}

\section{Tolga Uğur Esmer}

\section{(2) OpenEdition \\ 12 Journals}

\section{Electronic version}

URL: http://journals.openedition.org/ejts/4873

DOI: $10.4000 /$ ejts.4873

ISSN: $1773-0546$

Publisher

EJTS

\section{Electronic reference}

Tolga Uğur Esmer, «The Precarious Intimacy of Honor in Late Ottoman Accounts of Para-militarism and Banditry », European Journal of Turkish Studies [Online], 18 | 2014, Online since 01 July 2014,

connection on 16 February 2020. URL : http://journals.openedition.org/ejts/4873 ; DOI : 10.4000/ejts. 4873

This text was automatically generated on 16 February 2020.

(c) Some rights reserved / Creative Commons license 


\title{
The Precarious Intimacy of Honor in Late Ottoman Accounts of Para- militarism and Banditry
}

\author{
Tolga Uğur Esmer
}

1 This essay sets up a dialogue between discourses in the self-narrative of an irregular cavalryman (deli) Deli Mustafa that recounts the campaigns he took part from 1801/2 to 1825 and corpus of Ottoman archival sources written about Kara Feyzi, an irregular soldier (sekbân) and bandit leader who marshaled a successful, trans-regional organized crime network that pillaged Ottoman Rumeli from 1793 to 1823. Deli Mustafa, or Kabudlı el-Haccî Vasfî Efendi ${ }^{1}$ as he is fashioned on the title page of the only surviving manuscript of his narrative, provides rare glimpses into the tumultuous everyday life and moral dilemmas faced by countless Ottoman irregular soldiers, or "military laborers," who hailed from the Muslim peasantry and joined paramilitary bands either for social mobility or protection against similar types of bands that roamed the Empire during this period. ${ }^{2}$ Deli Mustafa's narrative and self-fashioning strategies help us understand what common Muslim men serving as itinerate soldiers had to do to make a living during this tumultuous period of Ottoman history, and most important, how they understood and explained their contentious ways of life as honorable and legitimate based on a common understanding of a masculine ethos and aesthetic shared by groups across social divides. ${ }^{3}$

2 In contrast, the corpus of official correspondence about Kara Feyzi reveals his spectacular trajectory from a common, itinerate soldier like Deli Mustafa into a wily bandit leader and imperial power broker. It also tells a larger story about how imperial governance came to depend on wide-spread networks of violence but became imbricated in their criminal activities during this period of Ottoman history. In the era of chronic wars with the Habsburg and Russian Empires, Kara Feyzi represented a new generation of Muslim warrior-entrepreneurs whose violent ways were once sanctioned by the state along its Danubian border to police these spaces and defend attacks against foreign armies during inter-imperial wars. However, by the late eighteenth century, 
especially during peacetime, they became agents of social disruption whose excesses gradually became a fact of everyday life. ${ }^{4}$ Different kinds of officials running the gamut from local ayân (notables) to prominent vezîrs (imperial ministers) documented this transformation over time in numerous dispatches they sent to Istanbul about Kara Feyzi. Together, this large corpus of sources sheds light on a repertoire of narrative strategies and tropes to which officials resorted to rationalize as well as mask their shady but often lucrative dealings with a man whom they nevertheless publically stigmatized as the enemy of the faith and state (hâ'inü'd-dîn ü devlet). Kara Feyzi and Deli Mustafa's stories complement each other as they juxtapose a common irregular soldier's strategies of self-fashioning vis-à-vis imperial officials with the these same types of officials' strategies of fashioning themselves vis-à-vis irregular soldier/bandits and, in the process, reflect all of these groups' own professional identities, concern for their reputations, and shared angst. Together, they shed light on much larger interpretative and moral communities forged upon the same kinds of "texts," narrative strategies, group experiences, exchange of material and symbolic resources, or simply a concept like honor woven throughout the narratives discussed below.

The concept of honor and shame in the social sciences as envisioned by twentiethcentury anthropologists of the Mediterranean has been the source of much controversy and criticism. Most criticisms revolve around the fact that honor and shame have been portrayed as timeless, immutable social structures throughout the Mediterranean, which, in turn, served as the basis for specious theories about the unity of the region (Albera 2006). ${ }^{5}$ However, this homogeneity was often based on superficial comparisons and assumed a priori rather than demonstrated (Herzfeld 1984). Skeptics have pointed out that the reification of the concept in anthropology was also rooted in northern European political agendas that sought to justify disparities of power in European politics and economy: the anthropologists' formulation of a rural, patriarchal, libidinous, mustached, always-ready-to-act-violently-on-honor Mediterranean male conveniently served to justify the southern man's inferior position (Pina-Cabral 1989). It has also been argued that in societies whose relations were analyzed by modern anthropologists in terms of honor and shame, the very subjects of research did not use these exact words in their own languages. ${ }^{6}$

Terms for honor only seldom appear in late eighteenth- and nineteenth-century Ottoman sources. Ottoman officials sometimes used the terms 'irz (honor), ehl-i 'irz zümresinden (from among honorable men), and edeb (good behavior; politeness), alongside their opposites like hetk-i 'irz (violation of honor), ehl-i şakavât zümresinden (men of evil stratagems), as well as edebsiz (without breeding) in their reports regarding Kara Feyzi's network but usually to describe bandit leaders' behavior in general and almost never in relation to the sexual violence that came with their much larger repertoire of crime. In contrast, in Bulgarian and Serbian sources chest/chast (honor) as well as obezchesten/obezčašćen (dishonored) appear in local sources that referred to Kara Feyzi's network's specific attacks on local communities and their excesses against Christian maidens (Nachev, Fermandjiev 1984: 239-240; Manolova-Nikolova, 1999), which suggests that while local communities were concerned with the honor of their womenfolk, this was neither the kind of honor nor part of the bigger picture that concerned imperial officials or the imperial center when it came to Kara Feyzi's insurgency. Rather than getting caught up in the semantics of honor and related concepts, this essay builds on recent historiography that revisits honor as a discourse that imperial officials, subjects, warriors, irregulars, and bandits all invoked in 
everyday relations as well as crisis. As opposed to approaching honor as something confined to individuals and face-to-face relations in rural communities, this essay approaches honor as a collective and institutional discourse that reflects the world views and apprehensions of broader interpretative and moral communities (Taylor 2011: 309). As Leslie Peirce points out in her contribution to this edition, honor and its constituent components such as shame, reputation, loyalty, fairness, honesty, and probity are relational concepts in that it takes communities to bestow or deny them to social actors. Indeed, this paper is concerned with these larger, trans-regional communities while being careful not to reify honor as something that can be harnessed by the state or one particular group.

5 It argues that honor and its relational components provide a flexible framework to study the ways in which sundry communities coped with endemic violence and multiple centers of power wielding (il)legitimate force in late Ottoman society. The concepts of honor embedded or implied in the narratives that will be discussed below reveal how different social groups made claims, competed for limited resources and status, negotiated what was right and wrong, and forged conflicting partnerships and allegiances with one another-however transient-for common pursuits. Rather than emphasizing honor as the mechanism of social organization in the absence of the reaches of the modern state, this essay illuminates the ways in which the discourse of honor (and its relational components) mediated the integration of individuals, groups, and local communities into much larger entities such as trans-regional networks and the structures of the state, since different manifestations of the state were ubiquitous in all of the disparate encounters reconstructed below. ${ }^{7}$ As it will be argued, the reliance of imperial governance on the trans-regional networks of violence to police and defend society resulted in a precarious intimacy that conventionalized the unconventional, insubordinate behavior of vast echelons of Ottoman society, making violent behavior a marker of prestige and masculinity.

\section{The Trope of Unemployment and Trans-Regional Networks of Violence}

Parts of Deli Mustafa's self-narrative in which he recalls his adventures in the Morea during the Greek Revolution (1821-1829) read like "rites of passage" into manhood in which a young warrior proudly boasts of beheading infidel (kâfir) insurgents, pillaging their communities, and enslaving their womenfolk-acts that would have won him the respect of his comrades, father (who accompanied him throughout his travels), commanders, and other target audiences of his narrative. ${ }^{8}$ Deli Mustafa emphasizes extreme forms of ritualistic violence and vengeance that he claims he visited onto his Christian adversaries, and he also boasts of daring risks he took whilst skillfully avoiding the same type of humiliation that he claims his cunning Greek adversaries sought to inscribe upon him and the Muslim community in general.

7 Throughout his account of his earlier journeys in Anatolia where he fought against rebellious paşas, bandits, or Kurdish tribes, however, Deli Mustafa makes only vague references to similar types of violence that his larger network wielded upon fellow Muslims. This suggests that the author understood the Greek Revolution to be a legitimate context for him to describe the full repertoire of the ritualistic violence and pillaging that men like him visited upon Ottoman society as a whole less discriminately. 
A careful reading of Deli Mustafa's account reveals the narrator's greater concerns with tensions and animosities within the Muslim community itself; the Greek Revolution merely permitted him to outline the building blocks of his masculine aesthetic with impunity. In particular, his account points to the larger struggles itinerate military forces had with their Muslim commanders as well as other ranks of soldiery like the Janissaries. It is in these descriptions running the gamut of trust, deception, and multiple, conflicting loyalties that marked relations among Muslim paramilitary networks, imperial commanders, and sundry local communities that one sees how the discourse of honor was crucial in governing social relations across communities and social groups.

8 Narratives like this combined with Ottoman archival sources give us insight into how men like Deli Mustafa and Kara Feyzi positioned themselves in relation to their immediate divisions or bands, larger, trans-regional networks, as well as the state. In this sense, Deli Mustafa's self-narrative resembles the narratives of police officials that Noemi Levy-Aksu focuses on in her contribution to this collection of essays in that honor was a central value around which the narrator promoted himself as well as his larger network of itinerate warriors who became the backbone of the Ottoman war machine and internal policing mechanisms yet were denied the professional status, pay, and dignity of traditional military bodies such as the Janissaries. It is in this context that one should understand Deli Mustafa's rhetoric of inclusion and exclusion on moral grounds, for he constantly juxtaposes himself and his delî comrades as honorable, loyal men concerned with protecting and upholding the faith and state to the ruthless stratagems of dishonorable Janissaries and imperial commanders who were all out for their own interests.

For instance, in an anecdote from his campaigns during the Greek Revolution, Deli Mustafa describes how he and his companions (along with dozens of female Greek captives they had acquired earlier) came upon insurgents near Kûmiye (Kymi, on the island of Euboea). After defeating and decapitating some of them, Mustafa and his men proceeded back to their camp with female slaves, the heads of insurgents, as well as what he claims were five thousand of their sheep. However, when they came upon Janissaries on the road, things immediately went awry when an enraged Janissary ağa (leader)who had his eyes on their loot complained that irregulars like the narrator were moving in on places ahead of the Janissaries and claiming first dibs on the Greek booty. Deli Mustafa adds that the ağa ordered his men to hold up Deli Mustafa and his comrades at gunpoint and confiscate their booty. In addition to stealing all of his female captives, decapitated Greek heads, and animals, Deli Mustafa also laments that the Janissaries robbed him of his horse, rendering him a simple foot soldier (...hemân piyâde kaldım; Ms. Or. 1551, 113a). ${ }^{9}$

Deli Mustafa recalls another episode in which Janissaries directly sullied his and his companions' honor, when they caught them conversing with Greek insurgents. After mocking Mustafa and his comrades by saying they feared infidels and were not worthy of the sultan's bread, one of Mustafa's insulted companions allegedly charged against the insurgents' trench on a horse unarmed, and as a result, was immediately shot dead off his horse: "...kâfirden korkaruz dimişler idi ve padişah etmeği (sic. ekmeği) sizlere harâmdir dimişler idi...," (ibid.: 72a-72b). Thus, Deli Mustafa's encounters with menacing Janissaries were not only just as dangerous as those with Greek insurgents, but they also speak to the ubiquitous problem non-salaried irregulars faced: though the imperial 
war machine relied on these men to police and defend the Empire, imperial elites and rival Janissaries denied these men professional status and respect, in addition to symbolic and material benefits they felt they were entitled to. The reader of Deli Mustafa's text can surmise that one's honor was something which men defended at all costs.

What can be discerned from Deli Mustafa's tales of his exploits as well as bad luck in keeping his booty is that they were inherently connected to his commanders' running vast trading networks of booty, slaves, and even body parts that they accumulated from different ranks of soldiery to sell to other networks in order to line their own pockets. ${ }^{10}$ Men like Deli Mustafa could not possibly deal with the logistics of such a vast enterprise and were thus the "wholesalers" that fed this much larger, lucrative economy. But being on the ground as a "wholesaler" was marked by brutal competition among the different ranks of Muslim soldiery, and it is in this context that one must consider the overall meaning of Deli Mustafa's narration of his heroics.

Among the hardships that Deli Mustafa laments the most, however, unemployment on account of treacherous commanders who frequently abandoned him and his companions features most in the text. This comes out most clearly in his account of travels in Anatolia where irregulars did not have license to pillage local communities to make a living as freely they did in the Morea. The narrator's discussion of this issue hints at how irregular forces understood their position as both contested commodities in inter-elite imperial intrigues and victims of the same whose suffering justified their collectively contentious ways. For instance, the narrator once explains that he and entire communities of his comrades were left unemployed ("kapusuz," i.e., without a patron) on account of their commanders' deceit. They were, therefore, forced to roam eastern and central Anatolia "from this village to that village" (bu köyde şu köyde) to get by (Ms. Or. 1551, 13a). The trope of unemployment duplicitously imposed upon them became an important bond between not only Deli Mustafa and his immediate companions in his division but also a vast community of Muslim itinerate warrior and bandit orders that spoke the same language of oppression across the entire Empire.

On this note, Deli Mustafa also reflects upon what he considered the "legitimate" as opposed to "illegitimate" plundering of local communities and blurry boundaries between banditry and the necessity of survival. He distinguishes between elite officials labeled "outlaws" (fermânl, those whose recalcitrance elicited an imperial edict against them) versus local, common "robbers" (harâmî, those engaged in unlawful activity) whom they encountered in skirmishes and battles throughout Anatolia. However, when it came to his and his companions' "roaming" Anatolia for sustenance, he is completely mum regarding what specific forms of coercion they exerted to expropriate food and resources from local populations. His account suggests that the itinerate soldiers' "roaming" without patrons became sort of an "accepted" practice since their superiors clearly realized that their bamboozling their men out of pay would result in their oppressing the local populations.

Deli Mustafa's recurrent talk of unemployment on account of being treated dishonorably by elites, a feature also implicit in the corpus of sources revolving around Kara Feyzi's insurgency, was of a special order: it was a key element in the discourse of a military laborer ethos, and as such, should be interpreted ideologically rather than literally. For instance, in his work on the sheep rustling and violence of highland pastoral communities in twentieth-century Crete, Michael Herzfeld points out how 
Cretan shepherds constantly manipulated tensions between local (village and Cretan) and national ethics in their everyday discourse, a rhetoric of self-justification balanced against self-recognition, through evoking an "ideology of hunger." Cretan highlander communities were well aware that their activities invoked official disapproval and punitive action. But they also maintained that animal theft was a particular feature of a klepht (i.e., nineteenth-century Greek bandit/freedom-fighter) ethos that was fashioned in Greek national narratives as the single-most important factor that helped undermine Turkish domination in the nineteenth century. In this sense, their cheerful insubordination against state laws and authority emphasizes their identity through the poetics of theft and narration of their community as mountain dwellers whose culture was crucial for establishing the Greek nation and placed them beyond the reproach of government authorities (Herzfeld 1985: 21). Indeed, what is striking is how this masculine ethos still discernible in Cretan communities in the twentieth-century was predicated upon appropriating the memory of ambiguous historical groups (i.e., klephts) that functioned very much like their Muslim counterparts that Deli Mustafa represented.

Whilst describing how he and thousands of irregulars were the victims of their superiors' intrigue and abuse, however, Deli Mustafa also boasts about how the paramilitary contingents to which he belonged were savvy networks capable of dealing with adversity brought onto them by their superiors and taking full advantage of their position as "contested commodities." Put simply, their strategy consisted of entertaining, soliciting, and accepting more advantageous employment propositions of rival factions, be they elite paşas or infamous "robbers." Itinerate warriors hedged their bets by talking with individuals and groups at war with one another, and loyalties could shift at any given moment because imperial officials and bandit bosses alike depended on them for manpower. ${ }^{11}$ To everyone involved, these volatile exchanges were constitutive of customary, acceptable behavior, which again highlights the precarious intimacy of governance and crime during this period of Ottoman history. For instance, while he and his companions lay under siege in Ardanuç castle under the patronage of a certain Baba Paşa stationed in nearby Erzurum, Deli Mustafa relates that one of their assailants, a local strongman named Kara Kadı began communicating with them and offered them clemency (bizlerere'y verüb) by giving them food, shelter, and presumably better pay in return for abandoning their positions at the castle. Deli Mustafa casually notes that he and his companions accepted the overtures of their assailant and moves on, but shortly afterwards he points out that Baba Paşa did in fact abandon him and 15,000 other irregulars (Schmidt 2002: 192). This episode points to the fact that these types of soldiery clearly understood their position as men whose skills were very marketable in Ottoman society. ${ }^{12}$ This is what put them in a position to negotiate better deals, salaries, and access to plunder for themselves if need be, thus prompting one to take the narrator's recurring trope of victimhood and unemployment with a grain of salt.

The dynamics Deli Mustafa conveys as common survival tactics for vast groups of military laborers compares well with similar dynamics that marked the career of Kara Feyzi a couple of decades earlier on the other side of the Empire in northern Rumeli. For example, in October 1795 the Protector of Belgrade (belgrad muhâfizl) reported that the retinue of Kara Feyzi was pillaging communities on his path to take the city in conjunction with rebellious Janissaries exiled from the region because their plundering 
of the local population was no longer condoned by the Ottoman government after 1791-92 when peace with the Habsburgs and Russians was made (B.O.A. HH 2402C). But what stands out in the paşa's correspondence is the fluid nature of the boundaries between his own military forces and Kara Feyzi's network, betraying the perpetual challenge officials faced in their efforts to recruit reliable forces to fight Kara Feyzi's insurgency. In this case El-Hac Mustafa Paşa voices his concern that his sekbân troops (irregulars) defending Belgrade were unreliable because Kara Feyzi's agents were among their ranks persuading them to join their network. However, the paşa's correspondence concomitantly betrays that he withheld the pay of his men and refused to allow them to return to their homes when their contracts ended in order to prevent them from joining the bandits. These imperial policies would only back-fire time and time again and encourage his various types of auxiliary soldiery to join Kara Feyzi's bands. ${ }^{13}$ Similar to the Kara Kadı option that Deli Mustafa alludes to, Mustafa Paşa's comments underline Kara Feyzi's recurrent contact and negotiations with low-ranking warriors who were supposed to protect local communities from him but elected to join him either because of the ill-treatment of their superiors or because Kara Feyzi's enterprise promised them a more lucrative deal or access to plunder.

Rather than trying to confirm or negate the truth of the claims of someone like Deli Mustafa or those officials reporting on Kara Feyzi who were often in cahoots with him, one can instead view the idiom of "unemployment" or "deceit" as an "ideological" toolbox shared by irregular soldiery that could help explain away individual as well as collective insubordination and violence. As Herzfeld points out with regard to highland shepherds in modern Crete, the poetic effect of introducing a narrative with allusions to hunger or some other conventionalized form of deprivation to explain violent behavior is precisely to identify the warrior's condition with that of larger society and to divert attention on the manly qualities of the act itself (Herzfeld 1985: 22). Men like Deli Mustafa are not simply lying when they talk about their deprivations. It is this imbalance between the limited power and financial means of what appear to be whimsical paşas and their dependence on irregulars like Mustafa to carry out their commissions that engenders the symbolism of unemployment. As Herzfeld suggests, perhaps a better word would be "dissatisfaction"-the dissatisfaction that both creates insubordination and becomes its most characteristic expression (id., ibid.). To military laborers, one of the true marks of manhood was the ability to hold one's head high in the face of adversity and repression that they came to expect from their commanders. This entails a high level of awareness of the implications of official rhetoric and an ability to mock and parody it both on the part of the irregulars and their superiors who very well knew that the former would prey upon subjects once they were tricked out of their pay.

This rhetoric of victimhood and deprivation, however, should not be interpreted in terms of class or social oppositions, strategies of resistance, or as the so-called "weapons of the weak," because even though he carefully distances himself from outright "rebellious behavior" that he attributes only to rebel paşas (fermânlı) and common criminals (harâmî), Deli Mustafa does hint that the vast networks of irregulars to which he belonged could be very ruthless-and very organized-in their dealings with imperial officials who double-crossed them. ${ }^{14}$ For instance, sometime in 1816 the aforementioned Baba Paşa contracted Deli Mustafa and his companions to travel to the Georgian borderland in the retinues of a certain Yegan Paşa and bölükbaşı (leader of 
irregular forces) Mahmud Kiran to lay siege to the fortress of Ahıska occupied by a paşa who was declared an outlaw by Istanbul (Schmidt 2002: 189-191). ${ }^{15}$ After completing this mission, the narrator reports that while they were awaiting further orders from their commander, they obtained news from informants that the inhabitants of the region had lodged complaints against Baba Paşa and his men to the sultan because his forces had allegedly deflowered no less than 500 local girls and decapitated several thousand Ahıskans in the process of fighting the aforementioned rebellious paşa. Noteworthy is how Deli Mustafa is careful to distance this violence-the very same ritualistic and sexual violence he hinted at in the Greek context-from himself and attribute it only to other divisions of Baba Paşa's forces.

But as a consequence of this intelligence and new developments, the author informs his audience that Baba Paşa was dismissed and ordered to assume a new post in Diyarbakir, which prompted Deli Mustafa and presumably thousands of other irregulars to rush back to Erzurum in order to collect their pay before the paşa skipped town for his new post. Baba Paşa, however, managed to weasel his way out of Erzurum without paying his men, and this prompted Deli Mustafa's bölükbaşı Mahmud Kıran and others whom the narrator strategically labels as "mischievous soldiers" to assault Baba Paşa's remaining hârem and possessions in Erzurum. Even though he again distances himself from the violence his comrades visited upon Baba Paşa's intimate relations/kin, Deli Mustafa nevertheless betrays the fact that he and his companions later joined forces with Mahmud Kiran after the Baba Paşa hârem incident (Schmidt 2002: 193-194). Thus, one can surmise that it was his consistent concern for portraying himself as an honorable warrior that dictated his circumspection. In other instances not involving Muslim officials' womenfolk, however, Deli Mustafa is much more explicit about his and his comrades' marching against commanders who conned them out of their pay and physically threatening them, thus pointing to how pacts of honor gone awry could backfire for the powerful as well as subordinate at any given moment. ${ }^{16}$

This reported attack on the paşa's hârem suggests that just like the Greek rebels Ottoman imperial elites could also be subject to the ultimate disgrace of having their womenfolk dishonored by Ottoman irregulars if they double-crossed the wrong men. As everyone involved in such an encounter understood, to harm, abuse, or abduct an enemy or his dependents-with the unstated presumption of using them for sex or slavery-was to level the greatest assault on his political honor: the violation of his household became symbolic of his failure to defend his domain and his dependents. As Leslie Peirce points out for earlier periods, the profit derived from abduction was more than symbolic. While taking captive bodies could be specifically aimed at inflicting dishonor, abduction typically accompanied other forms of theft and usurpation: part of the mystique of abduction and the fear it provoked was the lucrative violence that surrounded it (Peirce 2011: 312-3). In fact, Peirce argues that the "cult" of royal abduction intersected with the very self-fashioning of the Ottoman palace itself: as long as the Empire remained successful in conquering new territories and was led by warrior sultans of legendary prowess, the cult of abduction was a "positive force" for the honor and reputation of the Ottoman sultanate. However, it gradually turned into an act that threatened the state's authority late in the sixteenth century once the imperial armies were no longer able to conquer new territories and politically ambiguous strongmen within society targeted the sultan's subjects and used abduction 
as an assertion of honor, power, and valor against the sultan's vision of order (Peirce 2011: 311-8).

\section{Precarious Intimacy: Conflicting Loyalties, Deception, and "Licit" Practice}

21 Studying the sources documenting Kara Feyzi's long insurgency reveals that in addition to recruiting and coercing common Muslims and Christians into joining his network, he would also attract some of the most eminent imperial officials who hailed not only from Rumeli or Istanbul but also from far away regions across the Empire into joining his plundering confederacy. Indeed, here-in addition to their very different audiences - lies the fundamental difference between Deli Mustafa's narrative and the larger corpus of correspondence about Kara Feyzi. Nevertheless, some important congruencies are discernible. The former's narrative blames treacherous paşas who abandoned Deli Mustafa and his comrades for their having to plunder subjects to make a living. With this narrative device he probably not only ingratiated himself to likeminded audiences of irregular soldiers sitting around campfires listening to his stories but also helped them collectively explain their contentious ways. Similarly, the larger corpus of sources written about Kara Feyzi by different actors reveals common strategies in how imperial elites who became embroiled in his lucrative enterprise came to explain to more august audiences, the sultan and Imperial Council, their own comprising behavior and symbiotic relations with Kara Feyzi. Inevitably, imperial grandees resorted to abduction tropes, claiming that they were abducted by evil men (erbâb-ı ser') like Kara Feyzi, "seduced" by these tricksters' (hîle-kâr) power and promises, and then forced to terrorize and plunder the sultan's subjects against their will.

This section will therefore discuss how imperial elites involved in the Kara Feyzi saga gradually went from feeling it incumbent upon themselves to at least maintain a semblance of protecting and acting honorably vis-à-vis Ottoman subjects in their interactions with bandit networks to no longer having to keep up such appearances as Kara Feyzi's insurgency expanded in scope over the years. In the early years of Kara Feyzi's insurgency, imperial and local elites portrayed their respective retinues and collective behavior as bound by honor, probity, as well as fidelity to the faith and state. However, they would ultimately come to participate consistently and openly in this network's lucrative enterprise with little damage to their reputations and careers. They pursued their own agendas such as building powerful military retinues comprised of the very bandits they were supposed to repel in order to exhort more resources from both local communities and the imperial center as well as ensure that the retinues of other powerful figures did not threaten their interests. The fact that Kara Feyzi could forge increasingly intimate ties with the Empire's most powerful elites suggests that recalcitrant behavior became customary for many different groups of Ottoman society, high and low. For their own part, elite officials would consistently explain such behavior to the sultanate by employing abduction narratives similar to Deli Mustafa's unemployment trope in that they consistently served the same exculpatory function for their collective behavior. This section will discuss how different groups in society used the discourse of honor and its relational components to mediate social relations and negotiate status with surprising levels of parity. As I argue, this stemmed from 
officials' precarious dependency upon and intimacy with networks of violence like Kara Feyzi's to police and defend the Empire.

Kara Feyzi's rapid ascension onto the imperial stage as a broker of power on an imperial scale came around 1797-8, after years of successfully plundering large parts of Rumeli from Ottoman Serbia in the west to the very gates of Istanbul in the east. In fact, his interactions with high-ranking officials charged with the contradictory tasks of repelling and co-opting him and his vast network became increasingly intimate after an incident that took place in Filibe in September 1797.The incident brought the Empire's most prominent ministers, the Governor of Rumeli, Mustafa Paşa, and Governor of Anatolia, Seyyid Ali Paşa, into a head-on clash over the strategy regarding how the imperial government should best deal with Kara Feyzi's menace-by cooptation or outright extermination. While Mustafa Paşa advocated the former approach and at that very moment was negotiating with Kara Feyzi his cooptation into his retinue, his counterpart insisted upon the latter, and attacked Kara Feyzi's demobilized band in the middle of negotiations. In a furious exchange of dispatches between the vezirs and the sultan over this incident the two paşas attacked each other's character, loyalty to the state and faith, and ability to deal with the endemic problem of banditry in the Empire.

Though I deal with this encounter and its consequences at length elsewhere, here I would like to explore the role of honor in mediating one's standing in imperial politics and how it was harnessed by these respective actors. Mustafa Paşa was well aware of Kara Feyzi's penchant for reneging on the promises he made to imperial officials in the past. ${ }^{17}$ However, in light of this scandal and the threat Seyyid 'Ali Paşa posed to his reputation both locally and in Istanbul, portraying Kara Feyzi and his companions as trustworthy men served his goal of undermining his opponent. Kara Feyzi and his men were described as sincerely pleading for mercy and on the verge of being successfully rehabilitated as dependable servants (bende) who would conduct themselves henceforth with honor and decorum in the paşa's administration (“...müstâfir olup kendü 'irz ü edebleriyle dầire-yi hâlisânemizde edâ-yı hidmet..."). According to his testimony, it was Seyyid 'Ali Paşa and his Anatolian troops' cowardly, unsanctioned violence that fumbled what would have been Mustafa Paşa's successful cooptation of this notorious network.

In conjunction with trying to portray Kara Feyzi and his companions as honorable victims in this affair to suit his own agenda, Mustafa Paşa also conveys the shame (haclet-i 'azîm) that Seyyid 'Ali Paşa's intervention into local affairs and unauthorized use of force brought to his own reputation in Rumeli. The inhabitants of the city had heard that the followers of Kara Feyzi and his companions were actually pardoned, given amnesty, and even employed by the Governor of Rumeli, yet the Governor of Anatolia attacked these men along with innocent bystanders regardless, rendering Mustafa Paşa's word of honor void. Mustafa Paşa even cites the alleged speech of Kara Feyzi himself to comment on Seyyid 'Ali Paşa's honor, pointing out how the latter's soldiers cravenly attacked wounded men who could not defend themselves and then proceeded to rob, slaughter, and burn down the homes of local inhabitants in the process, thus conveying how the local community felt that they endured collateral damage as a result of what appeared a breach of honor. sultan and ordered to return back to Anatolia without fulfilling his exclusive 
commission (together with an army of 10,000 men) of destroying Kara Feyzi-all on account of his peer's specious reports about his conduct. Ali Paşa argued that Mustafa Paşa was both unable to control these bandits and that his administration was in cahoots with them. Both ministers' careers, nevertheless, soon declined and ended fatally because of their dealings with Kara Feyzi's larger networks, whereas, Kara Feyzi and his companions lived and plundered on having gained new visibility through this incident and profited from the imperial army's evacuation from Rumeli to meet the challenge of Napoleon's army in Egypt in the summer of 1798. ${ }^{18}$

As this incident suggests, in the early years of Kara Feyzi's insurgency, vezîrs were concerned with upholding their reputations in their constituent retinues and surrounding communities since they could be subject to public shame and disgrace for failing to uphold their words of honor, even when they were given to high profile bandit leaders. In contrast, bandit leaders like Kara Feyzi were immune to this shame and disgrace and seemed only to boost their reputations by breaking their promises and consistently duping local and imperial officials. In this sense, one can see not only how different groups were held to different criteria revolving around conflicting notions of honorable behavior based on class and status but also how disparate groups from below could manipulate elites into compromising situations whilst legitimating their own contentious ways (Stewart 2001). On dozens of occasions Kara Feyzi broke promises, feigned his willingness to betray companions, and even had his men continue to pillage an area so that he could have more leverage when negotiating with local leaders, yet the local populace consistently cooperated with him and his men because of the coercive power that his organization wielded over local society. ${ }^{19}$

What would become most alarming from the perspective of Istanbul, however, is that very soon after the Filibe scandal other high-ranking officials began to maraud and pillage Rumeli openly alongside Kara Feyzi's network thereby eliminating the need to maintain a semblance of acting honorably vis-à-vis the sultan's vision of order and subjects. On 23 June 1799, for example, a report reached Istanbul that another vezir commissioned to destroy Kara Feyzi, the Governor of Adana Hüseyin Paşa, had no scruples about openly joining Kara Feyzi's network in pillaging and slaughtering communities between the cities of Edirne and Kirca'ali. He apparently decided on this course of action upon hearing news that he would have to return to Anatolia because of his retinue's ineffectiveness in fighting Kara Feyzi's network (HH 2930). According to the report, in his negotiations with the Porte Hüseyin Paşa-like Seyyid 'Ali Paşa and others after him-demanded that rather than being ordered back to the Arab provinces disgraced and empty-handed, he should be promoted to the position of the Governor of Rumeli (ibid.). It appears from the records that Ottoman elites could pursue the tactics of joining the bandits with little damage to their track record in Istanbul, thus sending out the message to all groups of society that crime did, indeed, pay very well. ${ }^{20}$

One of the central exculpatory devices in the rehabilitation negotiations between the renegade vezir and the central government in Istanbul was the hackneyed abduction narrative in which the vezirs sought to explain to the sultan their choice of openly terrorizing Ottoman subjects alongside Kara Feyzi. For instance, another fallen vezîr, Koşancalı Halil Paşa, forged a long relationship with Kara Feyzi's network, pillaging for years regions throughout Rumeli stretching from northern Serbia along the Danube where they initially met to Greece and even the outskirts of Istanbul in the southeast by 1803. Among a number of sources that address Kara Feyzi and Koşancalı's 
relationship, a couple of related documents written in the winter of 1801 are particularly noteworthy. The first one dated 20 January 1801 was a dispatch that the Edirne Bostancıbaşı sent to Tayyar Mahmud Paşa, the Governor of Trabzon, who was another Anatolian vezîr commissioned to come to southern Rumeli to disband and destroy Kara Feyzi's network (HH 2436). The official reports that though Kara Feyzi and his companion Kara Mustafa were still devastating the Filibe region, the two were simultaneously sending in pleas for amnesty as well as the permission to remain there permanently in exchange for promising to reform their dishonorable ways (ibid.). The bostancıbaşı adds, however, that he indicated to them that in order to receive pardon, this time they would have to kill their high-ranking companion Koşancalı Halil Paşa themselves and personally deliver his "wretched head" to him (ibid.).

30 Another 9 February 1801 dispatch written by the same official, however, reports that in a separate interview Halil Paşa had a very different story to tell about his companions: he claimed that he was "wounded with fear for his life" because of the lying and slander of these malicious men (...erbâb-ı garaz ifk ve iftirâsindan nâş̧î cânımın havfindan mecrûh olduğum...) (HH 3388C). He asserts that he was "taken captive" (girif-târ) by these men and forced to serve deep among their ranks while he was still a vezîr of the Sublime Porte and that faced with such a helpless state of abandonment he was prevented from making amends for his previous string of crimes in Belgrade and forced to roam together with these bandits throughout Rumeli against his better judgment. According to the author of this report, Halil Paşa even pledged to betray Kara Feyzi and his companions if Tayyar Paşa could only trick them into leaving with him to Anatolia under his employ so that they could set up an ambush, but as was the case with many other similar stratagems that involved duping Kara Feyzi, such a plan never materialized. ${ }^{21}$ Being tricked by Kara Feyzi, whom officials often labeled a trickster, became a chronically viable excuse for their compromising behavior. ${ }^{22}$

\section{Conclusion}

31 A common feature of the interactions of different groups discussed in this essay is that though they were of varying social status, all of them were trying to fashion themselves as honorable men in dishonorable times. The manipulation of the discourse of honor and its relational components-shame, reputation, loyalty, and probity-governed how powerful groups capable of wielding brutal force with impunity interacted with one another in Ottoman society. This paper also argued that in tumultuous times that coincided with momentous historical events (e.g., the combined effects of widespread disorder due to chronic inter-imperial wars, Napoleon's invasion of Egypt, or the Greek Revolution), the perception of what constituted honorable behavior and decorum changed-again pointing to the danger of imagining honor as a timeless discourse and social structure.

32 It was the flexible, ambiguous discourse of honor that helped mediate relations in lieu of Islamic (shari'a) or sultanic (kanûn) law whose prescriptive injunctions and jurisdictions were not conceived to combat large scale paramilitary/bandit networks that operated as trans-regional organizations that preyed upon and disciplined Ottoman society. ${ }^{23}$ No local judge and his juridical tool-box could punish such large organizations. It was the proscriptive, fluid manner of custom and honor that dictated how different centers of power interacted with one another as well as local 
communities. Herein lay the contradictions of the state's precarious relationship with trans-regional networks of violence to police and defend its society. The state armed and depended on these groups to fight its wars and man its policing apparatuses in the retinues of governors and other officials, and yet, it tacitly acknowledged that a majority of these high-ranking officials institutionalized deceiving and mistreating these same men when it came to paying and provisioning for them. The imperial center, therefore, naturally found itself in a compromised position vis-à-vis these cheap but lethal military organizations that could prey upon and terrorize Ottoman subjects and officials alike for sustenance and leverage. Deli Mustafa's self-narrative sheds light on how individual members of these vast paramilitary orders fashioned themselves and their behavior vis-à-vis other groups of society; however, the corpus of sources written about Kara Feyzi provides us with a much larger interpretative community that integrates smaller voices like Mustafa's or local administrators' writing about Kara Feyzi together with the voices of the most powerful men in the Empire.

What these combined encounters point to is how ubiquitous the state was in the politics of honor on the ground. In their discussions of twentieth-century communities in the Mediterranean region anthropologists stressed that honor was a particular mode of communal interaction in the absence of moderating state institutions. Indeed, one of the most common criticisms of twentieth-century scholarship on the anthropology of honor and shame is that they were values mostly of country bumpkins living in rural, isolated mountain communities, and therefore, not representative of a so-called unity that anthropologists used by framing honor as a common denominator for the entire Mediterranean region. Case studies presented throughout this paper, however, all straddle the rural and urban divide and show how the discourse of honor was part of a trans-regional, customary forum in which all groups had to participate to negotiate material and symbolic resources.

Recently, historians of the early-modern Ottoman and Venetian Empires working on misogyny and abduction have reinserted the state into the discussion of honor. It has been argued that the sexual economy that tainted their victims, kin, and community also threatened the ruler himself by subjecting him to larger complaints about the integrity and legitimacy of imperial rule in general, and thus, concomitantly tainted his honor. For instance, Başak Tuğ's contribution to this journal issue points to how specific types of eighteenth-century sources such as complaint registers (şikâyet defterleri) verify how men and women themselves were adept at manipulating notions of dishonor (hetk-i 'irz) committed against womenfolk by local strongmen to persuade the central government to move against men that threatened their common interests. However, in the large corpus of sources ${ }^{24}$ written about Kara Feyzi that demanded the immediate attention of the imperial council and the sultan, violence against and the abduction of women were not the primary concerns of males high and low writing about Kara Feyzi's operation. Rather, these were gendered documents that reveal men across the social spectrum: vociferously defending their reputations, loyalty, and integrity whilst slandering those of others; staunchly fighting for vast material resources, weapons, commodities, and men; and insolently explaining away their compromising behavior with common tropes and phrases. In other words, although many of the men discussed in this essay were the usual culprits of misogyny, it is rather the awesome repertoire of crime and violence that accompanied sexual violence that reveals how honor and its relational components really mediated social relations 
among disparate groups of powerful men and different centers of power that dominated Ottoman society. The discourse of honor informed meso-level transactions that mediated how material and symbolic resources were distributed in a society in which most groups were tied to or affected by larger, trans-regional networks and their markets that bolstered what was still a sprawling empire. The ubiquity of these transactions questions the utility of talking about honor and shame as values that are pertinent only to peripheries and borderlands of empires or nation-states, since both Deli Mustafa as well as Kara Feyzi's stories point to how networks of violence moved throughout the Ottoman realm and exerted veritable power and influence whether they roamed near Istanbul, eastern Anatolia, or the Balkans.

What Kara Feyzi and Deli Mustafa's combined stories demonstrate is that the relationship between real power (i.e., the ability to wield extreme force) in the hands of sundry networks and the constant alternation between professed words of honor and allegiance versus deception among different groups of society caught in this zero-sum game point to how the resource of honor and its accompanying discourses had a "leveling affect" on social "class," pedigree, and distinction that put actors of humble social origins on par with elite actors. ${ }^{25}$ In other words, the rapid social mobility in Ottoman society based on one's ability to wield force points to how honor and its relational components was not a resource bound solely to social status and blood. Men like Deli Mustafa and Kara Feyzi were adept at manipulating officially recognized forms of protocol and decorum when they dealt with official representatives of the state.

While this essay focused on the moral communities of which Deli Mustafa, Kara Feyzi, and their interlocutors were part, at the same time it revealed the tensions of the heavily ideological, political, and historical relationships between their communities on the one hand and the state and other encompassing entities on the other in order to show how these groups did not understand Istanbul as their moral center (Herzfeld 1985: 20). Their strong sense of distinctive community shows that the concentric loyalties that marked Ottoman society did not represent secessionist threats to the state per se but offered alternative moral visions that justified, and valued, insubordinate behavior and inventive ways of disobedience (ibid: xii-xvi). It is the precarious intimacy of the encounter of these groups and the fact that they were all held to conflicting standards of decorum and behavior yet placed on equal footing because of their ability to wield shocking violence on the one hand and the state's reliance on this violence to police and defend its society on the other that insubordinate, unconventional behavior became conventionalized as a marker for manhood across social classes and organizations throughout Ottoman society.

BIBLIOGRAPHY 


\section{Non-Published Works}

B.O.A. Hatt-1 Hümâyûn (HH), 2402C, 2930, 2436, 3388C.

Ms. Or. 1551. Leiden University Library.

\section{Published Works}

Abu-Lughod, Lila (1986) Veiled Sentiments: Honor and Poetry in a Bedouin Society, Los Angeles, University of California.

Ahmet Cevdet Paşa (h.1309 [1891-2]) Tarih-i Cevdet, vol. X, Der-sa'âdet

Aksan, Virginia H. (2007) The Ottoman Wars, 1700-1870: An Empire Besieged, Harlow, Pearson / Longman.

Albera, Dionigi (2006) 'Anthropology of the Mediterranean: Between Crisis and Renewal', History and Anthropology 17 (2), pp. 109-133, URI: http://dx.doi.org/10.1080/02757200600633272.

Anscombe, Frederick F. (2006) 'Albanians and "mountain bandits”, in Anscombe, Frederick F. (ed.), The Ottoman Balkans, 1750-1830, Princeton NJ, Markus Wiener Publishers, pp. 87-113, URL: http://eprints.bbk.ac.uk/578/1/578.pdf.

Bracewell, Catherine Wendy (1992) The Uskoks of Senj: Piracy, Banditry, and Holy War in the SixteenthCentury Adriatic, Ithaca NY, Cornell University Press.

Campbell, John K. (1964) Honour, Family, and Patronage: A Study of Institutions and Moral Values in a Greek Mountain Community, Oxford, Clarendon Press.

Esmer, Tolga Uğur (2009) A Culture of Rebellion: Networks of Violence and Competing Discourses of Justice in the Ottoman Empire, 1790-1808, unpublished Ph.D. thesis, Chicago, University of Chicago.

Esmer, Tolga Uğur (2014a) 'Economies of Violence, Banditry and Governance in the Ottoman Empire around 1800', Past \& Present 224, pp. 163-199.

Esmer, Tolga Uğur (2014b) ‘The Confessions of an Ottoman “Irregular”: Self-Representation and Ottoman Interpretive Communities in the Nineteenth Century', Osmanlı Araştırmaları Dergisi - The Journal of Ottoman Studies 44 (forthcoming).

Herzfeld, Michael (1984) 'The Horns of the Mediterraneanist Dilemma', American Ethnologist 11 (3), pp. 439-54, URL: http://www.jstor.org/stable/644625.

Herzfeld, Michael (1985) The Poetics of Manhood: Contest and Identity in a Cretan Mountain Village, Princeton, Princeton University Press.

Horden, Peregrine; Purcell, Nicholas (2000) “"I Also Have a Moustache:” Anthropology and Mediterranean Unity', in Horden, Peregrine; Purcell, Nicholas, The Corrupting Sea: A Study of Mediterranean History, Oxford, Blackwell, pp. 485-529.

Krstić, Tijana (2011) Contested Conversions to Islam: Narratives of Religious Change in the Early Modern Ottoman Empire, Stanford CA, Stanford University Press.

Manolova-Nikolova, Nadja; Zheleva, Penka (ed.) (1999), ЛЕТОПИСНИ БЕЛЕЖКИ ОТ СРЕДНА ЗАПАДНА БъЛГАРИЯ, ХVI-ХХ ВЕК [Notes in Chronicles from Central-Western Bulgaria], Sofia, Lik.

Nachev, Ventseslav; Fermandjiev, Nikola (ed.) (1984) ПИСАХМЕ ДА СЕ ЗНАЕ: ПРИПИСКИ И ЛЕТОПИСИ [We Wrote to Let it Be Known: Marginalia and Chronicles], Sofia, Otechestvenija Front. 
Peirce, Leslie (2011) 'Abduction with (Dis)honor: Sovereigns, Brigands, and Heroes in the Ottoman World', Journal of Early Modern History 15 (4), pp. 311-29, URI: http://dx.doi.org/ $10.1163 / 157006511 X 577005$.

Peristiany, John G. (ed.) (1965), Honour and Shame: The Values of Mediterranean Society, London, Weidenfeld and Nicolson.

Pina-Cabral, João (1989) 'The Mediterranean as a Category of Regional Comparison: A Critical View', Current Anthropology 30 (3), pp. 399-406, URL: http://www.jstor.org/stable/2743537.

Pitt-Rivers, Julian (1977) The Fate of Shechem or the Politics of Sex: Essays in the Anthropology of the Mediterranean, Cambridge, Cambridge University Press.

Sant Cassia, Paul (2006) 'Better Occasional Murderers than Frequent Adulteries: Discourses on Banditry, Violence, and Sacrifice in the Mediterranean', in Coronil, Fernando; Skurski, Julie (eds.), States of Violence, Ann Arbor, University of Michigan Press, pp. 219-268.

Schmidt, Jan (2002) 'The Adventures of an Ottoman Horseman: The Autobiography of Kabudl 1 Vasfî Efendi, 1800-1825', in Schmidt, Jan, The Joys of Philology: Studies in Ottoman Literature, History and Orientalism (1500-1923) -I- Poetry, Historiography, Biography and Autobiography, Istanbul, İsis Yayınlar1, pp. 167-286.

Smiley, Will (2012) 'When Peace is Made, You will Again be Free:' Islamic and Treaty Law, Black Sea Conflict, and the Emergence of 'Prisoners of War' in the Ottoman Empire, 1739-1830, unpublished PhD. Dissertation, Cambridge, Cambridge University Queens' College.

Stewart, Charles (2001) 'Honor and Shame', in Smelser, Neil J.; Baltes Paul B. (ed.), International Encyclopedia of the Social and Behavior Sciences, pp. 6904-6907, URI: http://dx.doi.org/10.1016/ B0-08-043076-7/00884-6.

Taylor, Scott (2011) 'Honor in the Early Modern Eastern Mediterranean - an Introduction', Journal of Early modern History 15 (4), pp. 301-310, URI: http://dx.doi.org/10.1163/157006511X576998.

Tezcan, Baki (2010) The Second Ottoman Empire: Political and Social Transformation in the Early Modern World, Cambridge, Cambridge University Press.

\section{NOTES}

1. Leiden University Library, Ms. Or. 1551. The manuscript is dated 22 zi'l-ka'de 1249 (April 2, 1834). It was translated into English and commented upon by J. Schmidt (2002). In this paper I will be referring both to Schmidt's translation and to the actual manuscript. I have chosen to refer to the narrator as "Deli Mustafa" (which can also mean "Crazy Mustafa") since he refers to himself as such in the narrative as opposed to using the his embellished name (El-Haccî Vasfî Efendi) signed at the beginning of the text. As I will discuss below, the authorship of this account is in question.

2. In terms of nomenclature for different types of military forces in Ottoman history, there were many types of "irregular," mercenary-like forces such as delis, sarıca, levend, sekbân, etc. that the Ottomans used in warfare. For more on these types of forces, dubbed most recently as "military laborers" by V. Aksan because of the blurry boundaries among these different categories, see (Aksan 2007).

3. For more on Deli Mustafa's narrative, see Esmer 2014b.

4. For more on Kara Feyzi and how his insurgency began as a "legal" punishment against rebellious Serbian and other Christian communities along the Danube, see Esmer 2014a.

5. For comparisons, see Campbell 1964; Peristiany 1965; Pitt-Rivers 1977. 
6. See in particular Horden, Purcell 2000.

7. In this approach I am building on Herzfeld 1988. I am also in dialogue with Noemi Levy-Aksu's contribution to this edition, which approaches honor as both an individual and collective value of inclusion and exclusion deeply connected to ideas about morality as well as loyalty to larger networks and the state.

8. The authorship of this account is in question, as one can see from the mixing of genres in Deli Mustafa's narrative as well as how he sometimes addresses his audience directly. These features suggest that he most likely dictated a series of oral accounts over time to a scribe of limited literacy, given the mistakes in syntax, spelling, and word choice. For more on Deli Mustafa's narrative, the violence he describes in detail, and its overall meaning in Muslim interpretative communities at the time, see Esmer 2014b.

9. Being relegated to a simple foot soldier (piyâde) features as a common complaint or fear in Mustafa's narrative when he describes horses being stolen or shot beneath him. It seems that the author took pride in being a deli as opposed to a foot soldier or volunteer (gönüllü), but at one point, he hints that his leader was a volunteer leader (gönüller ağası).

10. At one point after a battle, for instance, Deli Mustafa alludes to the fact that various groups of soldiery would bring all of their mutilated trophies, booty, as well as bound Christian slaves to line up before their superior officers to sell their loot and receive "bonuses" (Schmidt 2002: 261).

11. Ottomanists working on the Balkans around this period have also noticed similar types of negotiation strategies among itinerate warriors in the Balkans, groups often labeled collectively as "Albanian." See Anscombe2006: 95-102.

12. Baki Tezcan has recently made the important point that one should see the increasing availability of mercenary-style irregular soldiery (e.g., sekbân) for inter- as well as intra-imperial warfare starting in the late sixteenth century as a direct result of imperial fiscal policies and the creation of a single currency zone (i.e., the "akçe zone") that united markets from Yemen to Hungary. That being said, while Tezcan's analysis portrays these irregulars as commodities to be bought and sold by Ottoman elites, this essay tries to study the other side of this picture, to show how this big mass of irregulars that scholars discuss were also very organized networks that were very adept at manipulating their status as "commodities" of the elite. See Tezcan 2010.

13. Ibid. For more on these recurring dynamics in the Kara Feyzi saga, see Esmer 2014a.

14. The fact that throughout the Kara Feyzi saga irregular and imperial soldiery consistently abandoned their commanders and joined lucrative bandit enterprises on the other side of the fortress walls only corroborates this.

15. According to Schmidt, Cevdet calls this bölükbaşı [division leader] Mahmud Tiran. See Ahmet Cevdet Paşa 1891-2, vol. X: 249.

16. For instance, near Erzincan another paşa, a certain Hafiz 'Ali Paşa, refused to pay Deli Mustafa and his fellow delis after their fulfilling their contracted services; thus, the narrator claims that they organized and marched against the paşa and were successful in extracting their pay through outright aggression. (Schmidt 2002: 198-199). In another instance, Mustafa notes that he had another quarrel (nizâ' edüb) with a paşa on the Persian frontier in skirmishes with Persian troops. Once the paşa cut off their monthly allowance, the irregulars were the ones who abandoned him at Kars and left for Sivas. (Ibid.: 207).

17. For more on sincerity, probity, and imperial versus bandit strategies at the negotiation table, see Esmer 2014a.

18. For more on the fates of these vezîrs in contrast to Kara Feyzi, see Esmer 2014a.

19. For more on Kara Feyzi and his network's surveillance, coercion, and access to vast amounts of information that gave his organization pre-emptive striking abilities, see Esmer 2014a.

20. Apparently, Hüseyin Paşa could act so boldly without any damage to his record, because he was soon afterwards appointed to combat Napoleon's forces in Egypt. See HH 2930. 
21. Ibid. Noteworthy, is that the aforementioned Mustafa Paşa also convinced the sultan to order Seyyid 'Ali Paşa to take Kara Feyzi and his retinue back to Anatolia; however, Kara Feyzi and his companions refused to fall for this trick.

22. For more examples of other vezîrs' and paşas' making such claims, see Esmer 2014a.

23. For more on the limits of law in dealing with large-scale crime, see Başak Tuğ's contribution in this EJTS issue.

24. For example, hatt-ı hümâyûn, cevdet dahiliye, cevdet 'adliye, mühimme defterleri, etc. but not sicil defterleri (court records) or şikâyet defterleri.

25. Like Peristiany, Pitt-Rivers, and Campbell writing before her, Abu-Lughod (1986) also saw blood and pedigree as critical to a person's honor and worth. Blood, she argued, is the authenticator of origin or pedigree and as such is crucial to Bedouin identity, and "asl, ancestry or nobility, is a crucial component in the "honor code." In the terms usually translated as honor, i.e., sharaf (şerif in Turkish), are implied a cluster of values that a morally excellent man is likely to have inherited: generosity, honesty, sincerity, keeping one's world of honor and loyalty to friends and family. In contrast, Peregrine Horden and Nicholas Purcell's work on honor and social relations questions such oppositions. See (Horden, Purcell 2000).

\section{ABSTRACTS}

This essay sets up a dialogue between the self-narrative of an irregular cavalryman (deli) Deli Mustafa that recounts the campaigns he took part in between 1801/2 and 1825 and the corpus of Ottoman archival sources written about Kara Feyzi, an irregular soldier (sekbân) and bandit leader who marshaled a successful, trans-regional organized crime network that pillaged Ottoman Rumeli from 1793 to 1823 . It does so in order to tell a larger story about how imperial governance came to depend on wide-spread networks of violence for defending and policing the Empire but became imbricated in their criminal activities during this period of Ottoman history. Together, Kara Feyzi and Deli Mustafa's stories shed light on much larger interpretative and moral communities forged upon the same kinds of "texts," narrative strategies, group experiences, exchange of material and symbolic resources, or simply a concept like honor woven throughout the narratives discussed below.

This essay builds on recent historiography that revisits honor as a discourse that imperial officials, subjects, warriors, irregulars, and bandits all invoked in everyday relations as well as crisis. Rather than emphasizing honor as the mechanism of social organization in the absence of the reaches of the modern state as it featured in twentieth-century anthropology of the Mediterranean, this essay illuminates the ways in which the discourse of honor (and its relational components) mediated the integration of individuals, groups, and local communities into much larger entities such as trans-regional networks and structures of the state. As it will be argued, the reliance of imperial governance on the trans-regional networks of violence to police and defend empire resulted in a precarious intimacy that conventionalized the unconventional, insubordinate behavior of vast echelons of Ottoman society, making violent behavior a marker of prestige and masculine aesthetic-indeed an enduring legacy of the Ottoman past from Serbia to Syria.

European Journal of Turkish Studies, 18 | 2014 
INDEX

Keywords: honor, Mediterranean, interpretative community, masculine ethos, Ottoman Empire, Balkans, Greek Revolution, self-narrative, ego-document, narrative strategies, irregulars, Kabudlı Vasfî Efendi, Kara Feyzi, imperial governance, networks of violence

\section{AUTHOR}

\section{TOLGA UĞUR ESMER}

Assistant Professor, Central European University, Hungary

Department of History 